\title{
STABILITY OF SCHISTOSOMA MANSONI PROGENY TO ANTISCHISTOSOMAL DRUGS ( ${ }^{*}$ )
}

\section{S U M M A R Y}

The susceptibility of the MAP Brazilian strain ( $F_{1}$ to $F_{5}$ progenies) of $\mathbf{S}$. mansoni to four antischistosomal drugs has been reported in a previous study. In the present investigation, progeny $F_{14}$ of the same strain, was tested for stability to the same 4 drugs. A new medication, Oltipraz (35,972 RP), was added to the study. Five groups of 12 mice infected with cercariae by tail immersion were treated with hycanthone, oxamniquine, niridazole, praziquantel and Oltipraz. An untreated group was used as control. Schistosomal activity was assessed by the localization of worms in the portal vein system, by oogram changes, and percentage of parasite reduction. The stability of the susceptibility of progeny $F_{14}$ did not change in relation to generations $F_{1}$ to $F_{5}$; the progeny was resistant to hycanthone and oxamniquine, but sensitive to niridazole, praziquantel and oltipraz. We emphasize the importance of the phenomenon of resistance of the worm in view of the fact that oxamniquine has been widely used in Brazilian areas where mansonic schistosomiasis is endemic.

\section{N T R O D U C T I O N}

The occurrence of resistant $\mathbf{S}$. mansoni strains has been reported by several investigators $2,3,6$. In a study on the behavior of a Brazilian strain (MAP) of the 'worm towards schistosomicidal drugs, were observed that progenies $\mathrm{F}_{1}$ to $\mathrm{F}_{5}$ 'were resistant to oxamniquine and hycanthone but sensitive to niridazole and praziquantel ${ }^{3}$. The patient (MAP) from whom the strain was isolated was treated once with hycanthone and twice with oxamniquine, with no parasitologic cure.

Ta evaluate the stability of the susceptibility of the MAP strain, an experimental therapeutic trial was carried out with the $F_{14}$ progeny.

In the present study we utilized a new drug, Oltipraz (35,972 RP), a new schistosomicidal drug that has been already tested in clinical trials 7,8 .

\section{MATERIAL AND METHODS}

After a previous study, we have been maintaining the MAP strain in our laboratory without exposure to schistosomicidal drugs by the following transfer scheme: Biomphalaria gla. brata - mice - Biomphalaria glabrata.

$F_{14}$ Cercariae obtained from B. glabrata snails were used to infect female albino mice (Swiss), by the tail immersion technique ${ }^{9}$. Each mouse was exposed to 100 cercariae. Drug treatment was carried out as follows 45 days after cercarial infection: 1 × $80 \mathrm{mg} / \mathrm{kg}$ hycanthone, intramuscularly; $1 \times 100 \mathrm{mg} / \mathrm{kg}$ oxamniquine; $5 \times 100 \mathrm{mg} / \mathrm{kg} /$ day niridazole; $5 \times 100$

(*) Study partially supported by the Superintendência de Controle de Endemias do Estado de Säo Paulo

(1) Universidade Estadual de Campinas. Instituto de Biologia, Departamento de Parasitologia. C.P. 6109, CEP 13.100 Campinas, S.P., Brazil 
DIAS, L. C. de S. \& OLIVIER, C. E. - Stability of Schistosoma mansoni progeny to antischistosomal drugs. Rev. Inst. Med. trop. São Paulo 27:186-189, 1985.

$\mathrm{mg} / \mathrm{kg} /$ day praziquantel, and $5 \times 125 \mathrm{mg} / \mathrm{kg} /$ day Oltipraz, orally. Each drug was applied to a different group of 12 mice. An untreated control group was formed to obtain miracidia for the next generation.

The mice were killed with a blow on the neck 10 days after treatment and the worms recovered by perfusion 9 . The schistosomicidal action was evaluated by the distribution of worms in the mesenteric vessels, percentage of mice with oogram changes and percentage of parasite reduction $1,4,9$.

\section{RESULTS}

We noticed that there was a high percentage of male worms in almost all groups, spe. cially in that treated with oxamniquine. We could also observe (Table I) the existence of two different patterns obtained by the therapeutic evaluation.

T A B L E I

Antischistosomal activity of drugs in mice experimentally infected with MAP strain of Schistosoma mansoni (progeny $F_{14}$ )

\begin{tabular}{|c|c|c|c|c|c|c|c|c|}
\hline \multirow{2}{*}{ Drugs } & \multicolumn{2}{|c|}{ Number of animals } & \multirow{2}{*}{$\begin{array}{c}\text { Mean worm } \\
\text { burden }\end{array}$} & \multirow{2}{*}{$\begin{array}{c}(\%) \\
\text { males }\end{array}$} & \multicolumn{2}{|c|}{ Distribution of schistosomes $(\%)$} & \multirow{2}{*}{$\begin{array}{l}\% \text { of mice with } \\
\text { oogram changes }\end{array}$} & \multirow{2}{*}{$\begin{array}{l}\% \text { parasit } \\
\text { reduction }\end{array}$} \\
\hline & Treated & Examined & & & $\begin{array}{l}\text { Liver and } \\
\text { portal vein }\end{array}$ & $\begin{array}{l}\text { Mesenteric } \\
\text { vessels }\end{array}$ & & \\
\hline Hycanthone & 12 & 10 & 24.3 & 62.6 & 26.7 & 73.3 & 0.0 & 2.9 \\
\hline Oxamniquine & 12 & 12 & 32.4 & 93.7 & 63.7 & 36.3 & 0.0 & 2.6 \\
\hline Praziquantel & 12 & 12 & 14.2 & 85.9 & 98.9 & 1.1 & 100.0 & 97.0 \\
\hline Niridazole & 9 & $\mathbf{g}$ & 9.2 & 85.5 & 92.8 & 7.2 & 100.0 & 44.6 \\
\hline Oltipraz & 10 & 9 & 16.6 & 75.2 & 100,0 & 0.0 & 100.0 & 100.0 \\
\hline Control & 12 & 10 & 38.7 & 74.7 & 44.2 & 55.8 & 0.0 & 0.0 \\
\hline
\end{tabular}

In the first pattern, represented by the groups treated with praziquantel, niridazole and Oltipraz we found a low percentage of worms in the mesenteric veins, $100 \%$ of altered oograms, and a high percentage of parasite reduction.

In the second pattern, showed by the groups treated with hycanthone and oxamniquine, the findings consisted by a greater amount of worms in the mesenteric veins, no alterations in the oograms, and a low percentage of parasite reduction.

The data of the first pattern have demonstrate some susceptibility to the antischistosomal used against those groups of worms, by the other hand the results obtained in the second pattern were very similar to the control group, confirming the worm resistance to the oxam. niquine and hycanthone.

One of the most important criteria to be evaluated in experimental analysis of susceptibility, in relation to antischistosomal drugs against $\mathbf{S}$. mansoni is the percentage of parasite reduction, since the surviving worms are the responsable by the therapeutic failure and potentially able to produce resistance progenies to this drugs 5,10 .

Although cercarian infection was performed on groups of 12 mice, it was not always possible to treat the same number of animals because of mortality during the 45-day period proceeding drug administration.

Worm mortality was not detected in the control group.

\section{DISCUSSION}

In the 14th progeny of the MAP strain, worm resistance remained stable when compared to the 1st to 5th progeny with respect to hycanthone and oxamniquine. The strain also showed stability of the susceptibility to niridazole and praziquantel.

In the present study, Oltipraz, which was being used for the first time against the MAP strain, showed clear activity. No cross-resistance with the other drugs studied here was shown by Oltipraz.

An interesting fact occurred in the present experiment. A relatively high percentage of male worms occurred in the infections espe- 
DIAS, L. C. de S. \& OLIVIER, C. E. - Stability of Schistosoma mansoni progeny to antischistosomal drugs. Rev. Inst. Med. trop. São Paulo 2\%:186-189, 1985.

cially in the group of mice treated with oxamniquine. Some investigators demonstrated that in infections by males only, most worms tend to be localized in the liver and portal vein 11,12 In the present study, although most of the worms were located in the liver and portal vein, in the animals treated with oxamniquine it could be seen that, when other parameters were utilized, the worms were resistant to the drug. However, the importance of 'well-balanced bisexual infections should be emphasized for the correct analysis of susceptibility to schistosomicidal drugs when the criterion of worm distribution is used.

\section{CONCLUSIONS}

In conclusion, our results show that: (a) the resistance and susceptibility to four drugs of an S. mansoni strain were stable in the $F_{14}$ progeny 'when compared to generations $\mathrm{F}_{1}$ to $\mathrm{F}_{5}$; (b) a new drug, Oltipraz, tested only on progeny $F_{14}$, was shown to be effective, with no cross-resistance with hycanthone and oxamniquine.

\section{RESUMO}

\section{Estabilidade de progênie de Schistosoma mansoni a drogas esquistossomicidas}

A suscetibilidade de linhagem brasileira (MAP), nas gerações $F_{1}$ a $F_{5}$ de $S$. mansoni a quatro drogas esquistossomicidas foi descrita em trabalho anterior. Na presente pesquisa os Autores testam a estabilidade da progênie $F_{14}$ da referida linhagem às quatro drogas e a um novo medicamento, Oltipraz (35,972 RP). Cinco grupos de 12 camundongos infectados com cercárias por meio da imersão da cauda, foram tratados com hycanthone, oxamniquine, niridazole, praziquantel e Oltipraz. Foi utilizado um grupo controle de camundongos infectados e não tratados. A atividade esquistossomicida das drogas foi avaliada pela localização dos vermes no sistema porta, pelas alterações no oograma e percentagem de redução de vermes. A suscetibilidadade dos vermes da geração $F_{14}$ mostrou-se estável em relação àquelas observadas nas progênies $F_{1}$ a $F_{5}$; a progênie $F_{14}$ de vermes foi resistente ao hycanthone e oxamniquine; todavia, foi sensivel ao niridazole, prazi- quantel e Oltipraz. Os Autores enfatizam a importância do fenômeno de resistência do verme em vista do fato do oxamniquine ser larga. mente utilizado em áreas do Brasil onde a esquistossomose mansônica é endêmica.

\section{ACKNOWLEDGEMENTS}

This work was made possible with funds provided by the Superintendência de Controle de Endemias (SUCEN).

We are indebted to Mr. L.H. Allement e Mrs. M.I.F. Locatelli for their technical assis tance.

\section{REFERENCES}

1. BRENER, Z. - Chemotherapy of experimental schistosomiasis. V - Studies of some techniques used for the assessment of drug activity. Rev. Inst. Med. trop. São Paulo 6: 167-170, 1965.

2. CAMPOS, R.; MOREIRA, A. A. B.; SETTE JR., H.; CHAMONE, D. A. F. \& SILVA, L. C. da - Hycanthone resistance in a human strain of Schistosoma mansoni. Trans. Royal Soc. Trop. Med. \& Hyg. 70: 261-262, 1976.

3. DIAS, L. C. de S.; PEDRO, R. de J. \& DEBERALDINI, E. R. - Use of praziquantel in patients with schistosomiasis mansoni previously treated with oxamniquine and/or hycanthone: resistance of Schistosoma mansoni to schistosomicidal agents. Trans. Royal Soc. Trop. Med. \& Hyg. 76: 652-659, 1982.

4. GÖNNERT, R, \& ANDREWS, P. - Praziquantel, a New Broadspectrum Antischistosomal Agent. Zeitschrift für Parasitenkunde 52: 129-150, 1977.

5. JANSMA, W. B.; ROGERS, S. H.; IIU, C. L. \& BUEDING, E. - Experimentally proüuced resistance of Schistosoma mansoni to hycanthone. Amer. J. Trop. Med. \& Hyg. 26: 926-936, 1977.

6. KATZ, N.; DIAS, E. P.; ARAUJO, N. \& SOUZA, C. P. - Estudo de uma cepa humana de Schistosoma mansoni resistente a agentes esquistossomicidas. Rev. Soc. Brasil. Med. Trop. 7: 381-387, 1973.

7. KATZ, N.; ROCHA, R. S. \& CHAVES, A. - Dose ranging clinical trial with Oltipraz in schistosomiasis mansoni. Rev, Inst. Med. trop. São Paulo 24: 40-48, 1982.

8. LEROY, J. P.; BARREAU, M.; COTREL, C.; JEANMART, C.; MESSER, M. \& BENAZET, F. - Laboratory Studies of 35,972 RP, a New Schistosomal Compound. In "Current Chemotherapy", Proceedings of 10th International Congress of Chemotherapy. American Society for Microbiology, Washington DC. 1978, pp. 148-150. 
DIAS, L. C. de S. \& OLIVIER, C. E. - Stability of Schistosoma mansoni progeny to antischistosomal drugs. Rev. Inst. Med. trop. São Paulo 2\%:186-189, 1985.

9. PELLEGRINO, J. \& KATZ, N. - Esperimental chemotherapy of schistosomiasis mansoni. In "Advances in Parasitology", Ben Dawes (Editor), Vol. 6. London and New York, Academic Press, 1968, pp. 233-290.

10. ROGERS, S. H. \& BUEDING, E. - Hycanthone resistance: Development in Schistosoma mansoni. Science 172: 1057-1058, 1971.

11. STANDEN, O. D. - The relationships of sex in Schistosoma mansoni to migration within the hepatic portal system of experimentally infected mice. Ann. Trop. Med. \& Parasit. 47: 139, 1953.

12. ZANOTTI, E. M.; MAGALHÄES, L. A. \& PIEDRABUENA, A. E. - Localização de Schistosoma mansoni no plexo porta de Mus musculus experimentalmente infectados por um só sexo do trematódeo. Rev. Saúde Públ. São Paulo 16: 220-232, 1982.

Recebido para publicação em 1/6/1984. 